\title{
Etiological Study of Thyroid Disorders in the Foot Hill Settlements of Pir Panjal Range
}

Hajam RA*, Rather GM and Kanth TA

Department of Geography and Regional Development, University of Kashmir, Srinagar-190006, India

*Corresponding author: Rafiq A Hajam, Department of Geography and Regional Development, University of Kashmir, Srinagar-190006, India, Tel: +91 (194) 227 2097; E-mail: rafiqahmad70@gmail.com

Rec date: Jul 15, 2015; Acc date: Sep 23, 2015; Pub date: Sep 25, 2015

Copyright: @ 2015 Hajam RA, et al. This is an open-access article distributed under the terms of the Creative Commons Attribution License, which permits unrestricted use, distribution, and reproduction in any medium, provided the original author and source are credited.

\begin{abstract}
The present research work is an attempt to find out the concentration of lodine $(\mathrm{I})$ in soil and water phases of the natural environment and its relationship with the human health in the foot hill settlements of Pir Panjal Range in Anantnag district of Kashmir valley. Also, socio-economic determinants of health were taken into due account. Firstly, the area was divided into altitudinal zones and soils classes. Then, the soil and water samples were taken from each soil type in each altitudinal zone and were analyzed by Atomic Absorption Spectrophotometer. The socioeconomic character of the area was analyzed through surveying the area by using structured household schedules. In this area, people rely mostly on locally cultivated food items because of their economic condition. The study highlights that about $19.5 \%, 42.9 \%$ and $37.6 \%$ households in the study area have low (Rs. $<5,000$ month $^{-1}$ ), medium (Rs. 5, 000-10, 000 month $^{-1}$ ) and high (Rs.>10, 000 month $^{-1}$ ) income status respectively. The study reveals that iodine content in all the soil $\left(0.970-1.230 \mathrm{mg} \mathrm{kg}^{-1}\right)$ and water $\left(1.6-4.2 \mu \mathrm{g} \mathrm{L}^{-1}\right)$ samples in all the altitudinal zones is less than the average values in the world soils $\left(2.8 \mathrm{mg} \mathrm{kg}^{-1}\right)$ and fresh waters $\left(8.7 \mu \mathrm{g} \mathrm{L}^{-1}\right)$. About $17.6 \%$ of the population in sample villages suffers from lodine Deficiency Disorders (IDDs). These IDDs can be ascribed to the scarcity of iodine in soils and drinking waters (and hence diet), and lifestyle. Attempts have been made to suggest certain remedial measures to minimize the magnitude of IDD sufferers in the study area.
\end{abstract}

Keywords: Iodine; Thyroid disorders; Foot hills; Cooking methods

\section{Introduction}

Trace elements are the elements present in the earth's crust in concentrations less than $0.1 \%\left(<1000 \mathrm{mg} \mathrm{kg}^{-1}\right)$ or those elements that are ordinarily present in plant or animal including human beings tissues in concentrations less than $0.01 \%\left(<100 \mathrm{mg} \mathrm{kg}^{-1}\right)$ of the organism's dry weight [1]. Trace elements are necessary for life in small amounts. They are components of haemoglobin, DNA, RNA, and various enzymes [2]. Trace metals play an important role in the synthesis of both proteins and nucleic acids. There is a standard requirement of each trace element for human health [3]. All essential trace elements either in excess states or in deficit states are known to create serious health problems particularly in the areas where these are regionally deficit [4] or surplus. The concentration of trace elements in soil, water or food items is mainly determined by the geological conditions of the area $[5,6]$.

The human body does not make its own iodine and is dependent on dietary sources and thus making it an essential part of our diet. The healthy adult human body contains 15-20 mgs of iodine, of which about $70-80 \%$ is in the thyroid gland. The normal intake and requirement of iodine is $100-150 \mu \mathrm{g} \mathrm{d}^{-1}[7,8]$.

It is an essential element that is critical for the normal growth and development, and wellbeing of all humans. Iodine deficiency is associated with reduced thyroid hormone synthesis, leading to increased thyroid stimulating hormone levels, which stimulates thyroid over growth and goiter [9]. The distribution of iodine is uneven in the biosphere. Its deficiency does not cause a mere enlargement of thyroid gland (endemic goiter), it can cause a variety of disorders called iodine deficiency disorders (IDDs) or thyroid disorders consisting of hypothyroidism, endemic cretinism, still-births, mental retardation, defects in vision, hearing and speech, and neuromuscular weakness. These disorders are mainly found in those people who live away from coastal areas, in mountainous areas, previously glaciated areas and the like. Even people living in coastal areas and on islands suffer from IDDs because sea salt does not contain iodine content as much as required by the people and due to their unsuitable habits [10].

W.H.O. estimated that about $20 \%$ to $60 \%$ of the world's population is iodine deficient [11] with most of the burden in developing countries. Mayer while working out the goiter incidence in Kashmir Valley during 2004-2005 found that Anantnag district (a part of foot hills) has the highest incidence of goiter and he suggested that nature of bedrock and soils is responsible for the variable goiter incidence in the valley [12].

According to a recent research conducted on school children of Kulgam district which is a part of the foot hills of Pir Panjal range, it was found that $18.9 \%$ suffer from Total Goiter Rate (TGR); $21.2 \%$ boys and $16.7 \%$ girls [13].

Since, the incidence/prevalence of thyroid disorders is a significant health problem covering an appreciable section of the society in the foot hills of Pir Panjal range, the present study was attempted to investigate the possible causes and factors both of the geochemical and socio-economic origins in the area.

\section{Study Area}

The area under present study is a part of the Kashmir region located roughly between the elevations of 1,800 meters to 3,000 meters above the mean sea level (m AMSL). The area lies between $33023^{\prime} 08^{\prime \prime} \mathrm{N}$ to 
$33065^{\prime} 90^{\prime \prime} \mathrm{N}$ latitudes and $74^{0} 5575^{\circ} 10^{\prime} 05^{\prime \prime}$ to $75^{\circ} 35^{\prime} 20^{\prime \prime} \mathrm{E}$ longitudes, covering an area of about $547.04 \mathrm{~km} 2$ (Figure 1) with a population of about $1,88,055$ [14]. The soils of the concerned area vary in origin from alluvial to lacustrine and glacial (Figure 2 and Table 1).

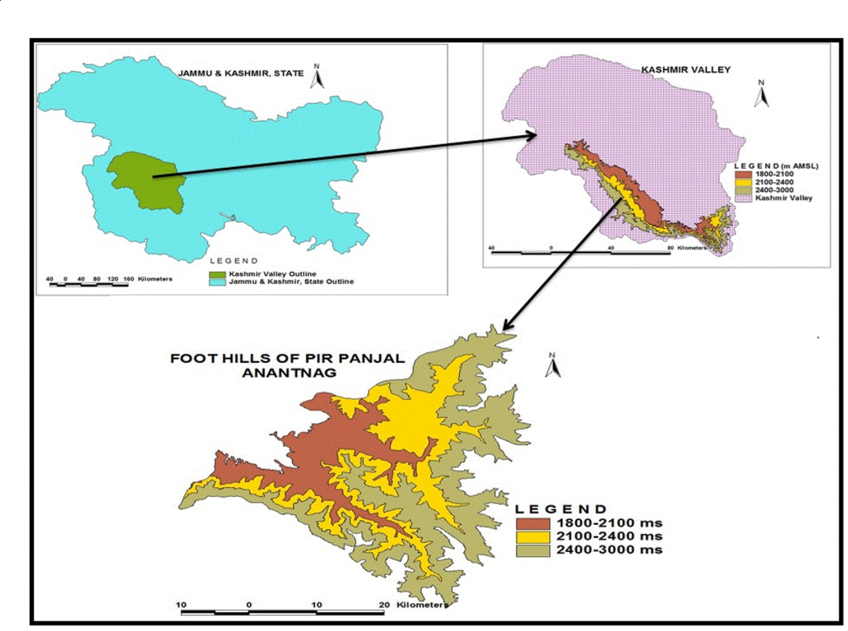

Figure 1: Location map.

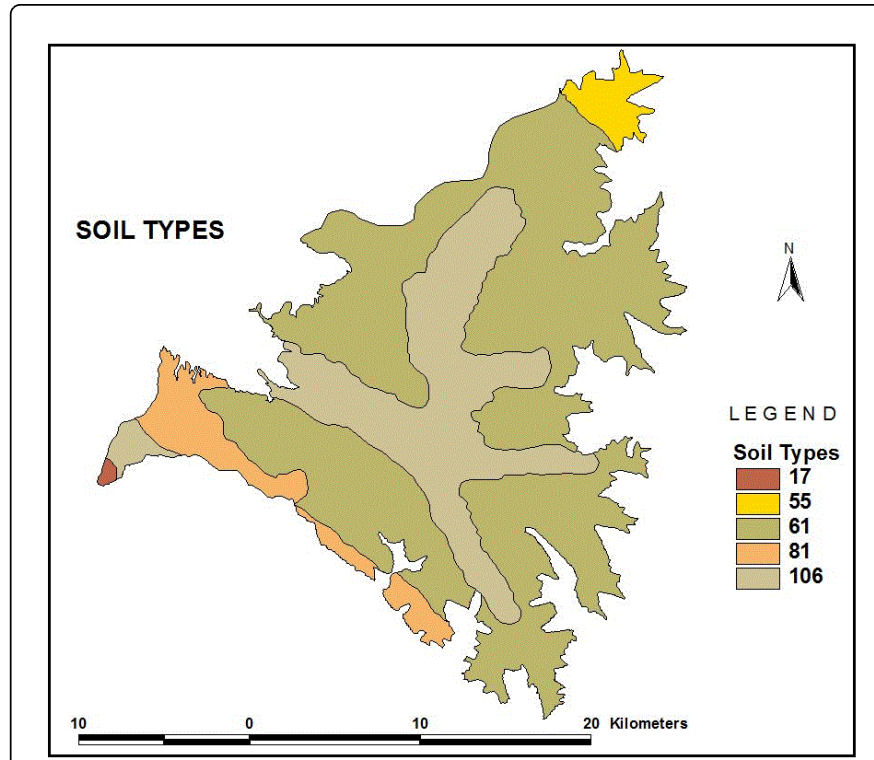

Figure 2: Modified from Soil Map of J \& K, ICAR, Nagpur-2010.

\begin{tabular}{|l|l|l|}
\hline Code & Description & Soil Type \\
\hline 17 & $\begin{array}{l}\text { Dominantly rock outcrops; associated with shallow, loamy, calcareous soils on steep to very steep slopes with loamy surface, } \\
\text { strong stoniness and severe erosion }\end{array}$ & $\begin{array}{l}\text { Lithic Cryorthents } \\
\text { associated with deep, well drained, coarse loamy, calcareous soils with loamy surface, moderate erosion and slight } \\
\text { gravelliness. }\end{array}$ \\
\hline 55 & $\begin{array}{l}\text { Medium deep, well drained, loamy-skeletal soils on moderate slopes with loamy surface, severe erosion and strong } \\
\text { stoniness; associated with medium deep, well drained, fine-loamy soils with loamy surface, moderate erosion and moderate } \\
\text { stonniness. }\end{array}$ & $\begin{array}{l}\text { Typic Udric Eutrochents/ } \\
\text { Dystrepts }\end{array}$ \\
\hline 81 & $\begin{array}{l}\text { Deep, moderately well drained, fine soils on very gentle slopes with loamy surface; associated with deep, well drained, fine- } \\
\text { loamy soils with loamy surface. }\end{array}$ & $\begin{array}{l}\text { Typic Hapludalfs/ } \\
\text { Dystric Eutrochrepts }\end{array}$ \\
\hline 106 & $\begin{array}{l}\text { Medium deep, well drained, fine loamy soils on moderate slopes with loamy surface and moderate erosion; associated with } \\
\text { shallow, excessively drained, loamy soils with loamy surface, moderate erosion and strong stonniness. }\end{array}$ & $\begin{array}{l}\text { Dystric Eutrochrepts/ } \\
\text { Lithic Udorthents }\end{array}$ \\
\hline
\end{tabular}

Table 1: Soil Types with Codes and Description. Source: Modified from Soil Map of J \& K, ICAR, Nagpur-2010.

\section{Data base and methodology}

A comprehensive methodology has been adopted to carry out the present study. Figure 3 shows the general data base and methodological scheme divided into many related steps in order to accomplish the objectives of the present work.

\section{GIS techniques}

The study area was delineated from Survey of India (SOI) toposheets of 1:50,000 scale of 1971 with numbers as $43 \mathrm{O} / 2,43 \mathrm{O} / 3$, $43 \mathrm{O} / 6$ and $43 \mathrm{O} / 7$ with the help of Arc View 3.2a software. The base contour was taken as 1,800 th $\mathrm{m}$ AMSL and top one as $3,000^{\text {th }} \mathrm{m}$ AMSL [15]. These two contours were connected on the lateral sides by taking the watershed limits through digitization.
By digitizing $2,400^{\text {th }} \mathrm{m}$ contour, the area under study was divided into two altitudinal zones, namely, Lower Foot Hills (LFHs) and Upper Foot Hills (UFHs) varying in altitude from $1,800^{\text {th }}-2,400^{\text {th }} \mathrm{m}$ and 2,400 th $-3,000^{\text {th }} \mathrm{m}$ respectively. The LFHs are characterized by good permanent human occupancy while as the UFHs experience mostly seasonal human inhabitations. By digitizing $2,100^{\text {th }} \mathrm{m}$ contour, the LFHs were further sub-divided into two sub-zones namely, LFHs-1 and LFHs-2 varying in elevation from 1,800 th- $2,100^{\text {th }} \mathrm{m}$ and $2,100^{\text {th }}-2,400^{\text {th }} \mathrm{m}$ (Figure $4 \mathrm{a}$ ) for comparative analysis.

Stratified random sampling technique was used for the selection of sample sites (sample villages, soil and water sample sites) and sample households as shown in tables 2 and 3 and figures $4 b, 5 a$ and $5 b$. 
Citation: Hajam RA, Rather GM, Kanth TA (2015) Etiological Study of Thyroid Disorders in the Foot Hill Settlements of Pir Panjal Range. J

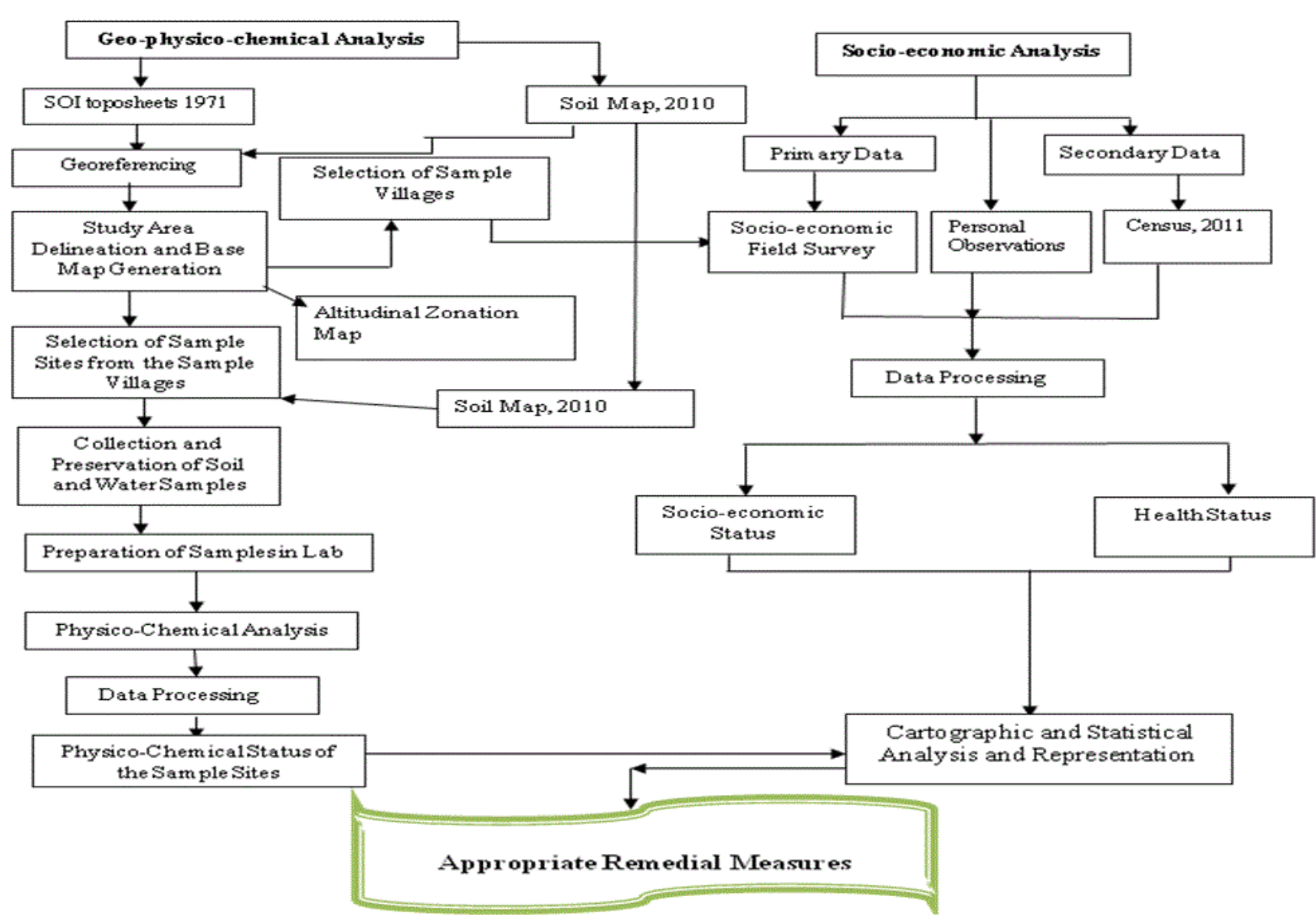

Figure 3: Flow Chart of Methodology.
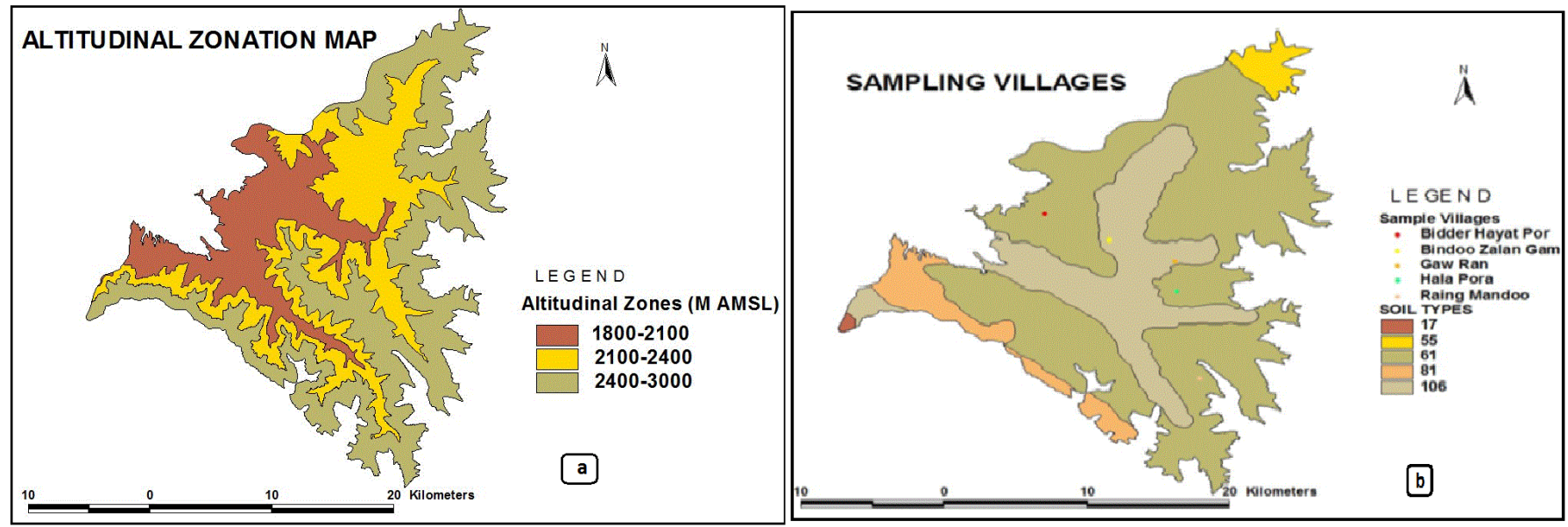

Figure 4: a) Altitudinal zonation map and b) Sampling villages. 
Citation: Hajam RA, Rather GM, Kanth TA (2015) Etiological Study of Thyroid Disorders in the Foot Hill Settlements of Pir Panjal Range. J
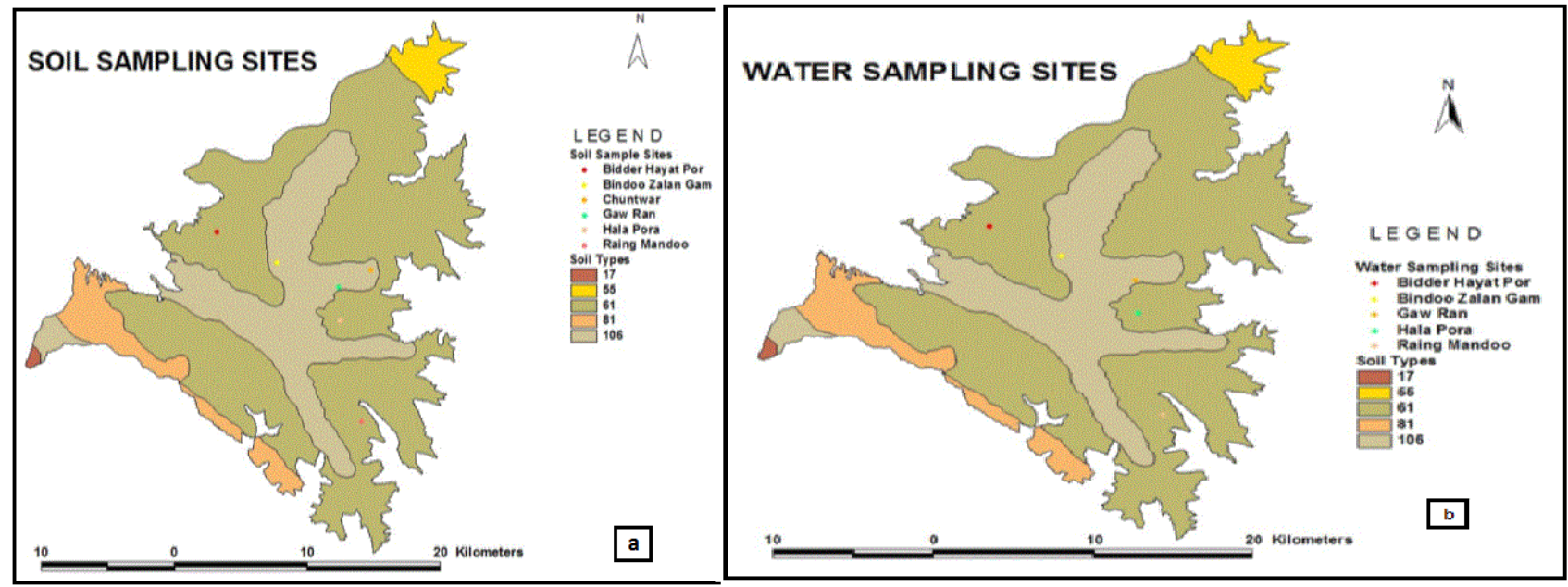

Figure 5: a) Soil Sampling Sites, and b) Drinking Water Sampling Sites.

\begin{tabular}{|c|c|c|c|c|c|c|c|c|c|}
\hline $\begin{array}{l}\text { Macro Regions } \\
\text { (Altitudinal } \\
\text { Zones in } \mathrm{m} \\
\text { AMSL) }\end{array}$ & $\begin{array}{l}\text { Micro Regions } \\
\text { (Sub- } \\
\text { altitudinal } \\
\text { Zones in } \mathrm{m} \\
\text { AMSL) }\end{array}$ & $\begin{array}{l}\text { Sample } \\
\text { Villages }\end{array}$ & $\begin{array}{l}\text { Total No. of } \\
\text { Households in } \\
\text { the Sample } \\
\text { Villages }\end{array}$ & $\begin{array}{l}\text { Number of } \\
\text { Households } \\
\text { Surveyed }\end{array}$ & $\begin{array}{l}\text { Percentage of } \\
\text { Surveyed } \\
\text { Households to } \\
\text { total } \\
\text { Households }\end{array}$ & $\begin{array}{l}\text { Soil Type } \\
\text { (Codes) }\end{array}$ & $\begin{array}{l}\text { Number of } \\
\text { Samples } \\
\text { Taken }\end{array}$ & $\begin{array}{l}\text { Main } \\
\text { Water } \\
\text { Source }\end{array}$ & $\begin{array}{l}\text { No. of } \\
\text { Samples } \\
\text { Taken }\end{array}$ \\
\hline \multirow{4}{*}{$\begin{array}{l}\text { Lower Foot Hills } \\
\text { (LFHs)-1,800-2, } \\
400\end{array}$} & \multirow[t]{2}{*}{$\begin{array}{l}\text { LFHs-1 } \\
(1,800-2,100)\end{array}$} & $\begin{array}{l}\text { Bidder Hayat } \\
\text { Pora }\end{array}$ & 77 & 08 & $>10$ & 61 & 01 & $\mathrm{TSg}$ & 01 \\
\hline & & $\begin{array}{l}\text { Bindoo Zalan } \\
\text { Gam }\end{array}$ & 519 & 52 & $>10$ & 106 & 01 & TSm & 01 \\
\hline & \multirow{2}{*}{$\begin{array}{l}\text { LFHs-2 } \\
(2,100-2,400)\end{array}$} & Hala Pora & 292 & 29 & $<10$ & 61 & 01 & TSm & 01 \\
\hline & & Gaw Ran & 252 & 25 & $<10$ & 106 & 01 & $\mathrm{TSg}$ & 01 \\
\hline \multirow{2}{*}{$\begin{array}{l}\text { Upper Foot Hills } \\
\text { (UFHs)-2,400-3, } \\
000\end{array}$} & \multirow[t]{2}{*}{$\begin{array}{l}\text { UFHs } \\
(2,400-3,000)\end{array}$} & $\begin{array}{l}\text { Raing } \\
\text { Mandoo }\end{array}$ & 143 & 14 & $<10$ & 61 & 01 & $\mathrm{Sg}$ & 01 \\
\hline & & Chuntwar & 00 & 00 & 00 & 106 & 01 & 00 & 00 \\
\hline \multicolumn{3}{|l|}{ Total } & 1,283 & 128 & 10 & & 06 & & 05 \\
\hline
\end{tabular}

Table 2: Sample frame. source: generated by the authors.

\begin{tabular}{|c|c|c|c|c|}
\hline $\begin{array}{l}\text { Macro Regions (Altitudinal } \\
\text { Zones in meters AMSL) }\end{array}$ & $\begin{array}{l}\text { Micro Regions (Sub- } \\
\text { altitudinal Zones in meters } \\
\text { AMSL) }\end{array}$ & Sample Villages/Sites & $\begin{array}{l}\text { Sample Village/Site } \\
\text { (Codes) }\end{array}$ & Geo-Coordinates (Lat./Long.) \\
\hline \multirow{4}{*}{$\begin{array}{l}\text { Lower } \quad \text { Foot } \\
\text { (LFHs)-1,800-2,400 }\end{array}$} & \multirow[t]{2}{*}{ LFHs-1 1,800-2,100 } & Bidder Hayat Pora & SS1-ANG & 33036 '23" N \& 750 17’54"E \\
\hline & & Bindoo Zalan Gam & SS2-ANG & $33034^{\prime} 45^{\prime \prime} N \& 750$ 18'17"E \\
\hline & \multirow[t]{2}{*}{ LFHs-2 2,100-2,400 } & Hala Pora & SS3-ANG & 33030 '40" N \& 75021'07"E \\
\hline & & Gaw Ran & SS4-ANG & $33035^{\prime 2} 24$ " N \& 75021'26"E \\
\hline \multirow{2}{*}{$\begin{array}{l}\text { Upper } \quad \text { Foot } \\
\text { (UFHs)-2,400-3,000 }\end{array}$} & \multirow[t]{2}{*}{ UFHs $2,400-3,000$} & Raing Mandoo & SS5-ANG & 330 26'38" N \& 750 22'24"E \\
\hline & & Chuntwar & SS6-ANG & $33034^{\prime} 15^{\prime \prime} N \& 75024^{\prime} 08^{\prime \prime} E$ \\
\hline
\end{tabular}

Table 3: Sample Villages and Sample Sites with codes and geo-coordinates. Source: SOI toposheets, 197. 
Citation: Hajam RA, Rather GM, Kanth TA (2015) Etiological Study of Thyroid Disorders in the Foot Hill Settlements of Pir Panjal Range. J

Page 5 of 10

\section{Field work}

The soil samples were collected in clean unused polythene bags and were labeled properly. A clean spade was used to take the soil samples. In order to reduce variability, a composite sample was obtained from each sample site. A composite sample comprised of five sub-samples taken from each sample site in $10 \mathrm{~m} \times 10 \mathrm{~m}$ grid format. Four subsamples were taken from four corners of the square and one from the center. Soil samples were taken from depths of 0-20, 0-40 and 0-60 cm in relation to different major land uses i.e., agricultural, horticultural and forest respectively $[16,17]$. Water samples were collected in clean unused plastic bottles from the selected sample sites and were labeled properly and reached to the lab within $24 \mathrm{~h}$. Both types of samples were analyzed in Research Centre for Residue and Quality Analysis Lab, SKUAST, Shalimar. The socio-economic survey was done through the structured schedules to give the socio-economic picture of the area and to assess the dependence of people on local food items, income status, methods of cooking, households using iodized salt and boiled drinking water and percentage of households purchasing food from the market. The data regarding the prevalence of IDDs was collected from the prescriptions given by the registered practitioners.

\section{Lab work}

The soil samples were air-dried, crushed with a wooden roller, passed through a 10 mesh $(<2 \mathrm{~mm})$ sieve, and then ground in an agate mortar. The recovered $<63 \mu \mathrm{m}$ particles were separated for chemical analysis. The samples were analyzed under Atomic Absorption Spectrophotometer (AAS-4141, Electronic Corporation Limited, India). A total concentration of I was determined after 4-acid digestion ( $\mathrm{HF}, \mathrm{HClO}_{4}, \mathrm{HNO}_{3}$ and $\mathrm{HCl}$ ) by AAS. The samples were analyzed for iodine, $\mathrm{pH}$ and organic matter $(\mathrm{OM})$.

\section{Results and Discussions}

\section{Concentration of iodine in the soil and drinking water sources}

The study showed that the soils and drinking water sources of the foot hills of Pir Panjal range in Anantnag district are deficient in iodine content in all the altitudinal zones (Tables 4 and 5) and have iodine content less than the world averages.

\begin{tabular}{|c|c|c|c|c|c|}
\hline Macro Regions & Micro Regions & Sample Sites & Water Source & lodine Conc. ( $\mu \mathrm{g} \mathrm{L}-1)$ & $\mathrm{pH}$ \\
\hline \multirow{4}{*}{ LOWER FOOT HILLS } & \multirow{2}{*}{$\begin{array}{l}\text { LFHs-1 } \quad(1,800-2,100 \quad \mathrm{~m} \\
\text { AMSL) }\end{array}$} & SS1-ANG & TSg & 1.6 & 7.53 \\
\hline & & SS2-ANG & TSm & 2.5 & 7.85 \\
\hline & \multirow{2}{*}{$\begin{array}{l}\text { LFHs-2 } \quad(2,100-2,400 \quad \mathrm{~m} \\
\text { AMSL) }\end{array}$} & SS3-ANG & $\mathrm{TSm}$ & 3.9 & 7.87 \\
\hline & & SS4-ANG & $\mathrm{TSg}$ & 4.2 & 7.54 \\
\hline Mean & & & & 3.05 & 7.7 \\
\hline UPPER FOOT HILLS & $\begin{array}{l}\text { UFHs } \quad(2,400-3,000 \quad \mathrm{~m} \\
\text { AMSL) }\end{array}$ & SS5-ANG & $\mathrm{Sg}$ & 4.1 & 7.75 \\
\hline Mean & & & & 4.1 & 7.75 \\
\hline Mean & & & & 3.26 & 7.71 \\
\hline Standard Deviation & & & & $1.6600 \mu \mathrm{g} \mathrm{L}-1$ & \\
\hline Coefficient of SD & & & & 0.5092 & \\
\hline Coefficient of Variation & & & & $50.92 \%$ & \\
\hline
\end{tabular}

Table 5: Iodine Content and pH of Water sources. Source: Based on water sample analysis done by the authors, 2013. Note: TSg=Tap fed by a spring, TSm=Tap fed by a stream, Sg=Spring.

\begin{tabular}{|c|c|c|c|c|c|c|c|}
\hline \multirow[t]{2}{*}{$\begin{array}{l}\text { Macro } \\
\text { Region }\end{array}$} & \multirow[t]{2}{*}{$\begin{array}{l}\text { Micro } \\
\text { Region }\end{array}$} & \multirow[t]{2}{*}{$\begin{array}{l}\text { Sample } \\
\text { Villages }\end{array}$} & \multirow{2}{*}{$\begin{array}{l}\text { Number of Persons } \\
\text { Surveyed } \\
(100 \%)\end{array}$} & \multirow[t]{2}{*}{$\begin{array}{l}\text { Age } \\
\text { Groups }\end{array}$} & \multirow[t]{2}{*}{ Sex } & \multicolumn{2}{|c|}{$\begin{array}{l}\text { Number of Persons Suffering From IDDs (\% cases to } \\
\text { total) }\end{array}$} \\
\hline & & & & & & $\begin{array}{l}\text { Person Suffering from IDD } \\
\text { (Thyroid) }\end{array}$ & $\begin{array}{l}\text { Person Suffering from no } \\
\text { IDD }\end{array}$ \\
\hline \multirow[t]{6}{*}{ LFH } & \multirow[t]{6}{*}{ LFHs-1 } & \multirow{6}{*}{$\begin{array}{l}\text { SS1- } \\
\text { ANG }\end{array}$} & 6 & \multirow{2}{*}{$\begin{array}{l}\text { Children } \\
(1-14)\end{array}$} & $\mathrm{M}$ & $1(16.6)$ & $5(83.4)$ \\
\hline & & & 4 & & $\mathrm{~F}$ & $1(25)$ & $3(75)$ \\
\hline & & & 8 & \multirow{2}{*}{$\begin{array}{l}\text { Adults } \\
(15-50)\end{array}$} & $M$ & $2(25)$ & $6(75)$ \\
\hline & & & 8 & & $\mathrm{~F}$ & $2(25)$ & $6(75)$ \\
\hline & & & 1 & \multirow{2}{*}{$\begin{array}{l}\text { Olds } \\
(>50)\end{array}$} & $M$ & $0(0)$ & $1(100)$ \\
\hline & & & 1 & & $\mathrm{~F}$ & $0(0)$ & $1(100)$ \\
\hline
\end{tabular}


Citation: Hajam RA, Rather GM, Kanth TA (2015) Etiological Study of Thyroid Disorders in the Foot Hill Settlements of Pir Panjal Range. J

\begin{tabular}{|c|c|c|c|c|c|c|c|}
\hline & & Total & 28 & & & $6(21.4)$ & 22 (79.6) \\
\hline & & ss2- & 36 & Children & $M$ & $7(19.4)$ & 29 (80.6) \\
\hline & & ANG & 40 & $(1-14)$ & $\mathrm{F}$ & $8(20.0)$ & $32(80.0)$ \\
\hline & & & 52 & Adults & $M$ & $7(13.5)$ & 45 (86.5) \\
\hline & & & 52 & $(15-50)$ & $\mathrm{F}$ & $9(17.3)$ & 43 (82.7) \\
\hline & & & 27 & Olds & $M$ & $3(13.1)$ & 20 (86.9) \\
\hline & & & 23 & $(>50)$ & $F$ & $5(18.5)$ & $22(81.5)$ \\
\hline & & Total & 230 & & & $39(16.9)$ & 191(83.1) \\
\hline & Total & & 258 & & & $45(17.4)$ & $213(82.6)$ \\
\hline & LFHs-2 & Ss3- & 14 & Children & $M$ & $3(21.4)$ & 11 (78.6) \\
\hline & & ANG & 9 & $(1-14)$ & $\mathrm{F}$ & 1(11.1) & $8(88.9)$ \\
\hline & & & 29 & Adults & $M$ & $5(17.2)$ & $24(81.8)$ \\
\hline & & & 28 & $(15-50)$ & $\mathrm{F}$ & $5(17.8)$ & 23(82.2) \\
\hline & & & 15 & Olds & $M$ & $2(13.4)$ & 13(85.6) \\
\hline & & & 15 & $(>50)$ & $\mathrm{F}$ & $2(13.4)$ & $13(85.6)$ \\
\hline & & Total & 110 & & & $18(16.4)$ & $92(83.6)$ \\
\hline & & SS4- & 16 & Children & $M$ & $3(18.7)$ & $13(81.3)$ \\
\hline & & ANG & 12 & $(1-14)$ & $\mathrm{F}$ & $1(8.4)$ & $11(91.6)$ \\
\hline & & & 25 & Adults & $M$ & $4(16.0)$ & $21(84.0)$ \\
\hline & & & 24 & $(15-50)$ & $F$ & $5(20.8)$ & 19(79.2) \\
\hline & & & 7 & Olds & $M$ & $1(14.3)$ & $6(85.7)$ \\
\hline & & & 7 & $(>50)$ & $\mathrm{F}$ & $1(14.3)$ & $6(85.7)$ \\
\hline & & Total & 91 & & & 15 (16.5) & $76(83.5)$ \\
\hline & Total & & 201 & & & $33(16.4)$ & 168(83.6) \\
\hline Total & & & 459 & & & $78(17.0)$ & $381(83.0)$ \\
\hline UFHs & UFHs & Ss5- & 14 & Children & $M$ & $3(21.4)$ & $11(78.6)$ \\
\hline & & ANG & 11 & $(1-14)$ & $\mathrm{F}$ & $2(18.2)$ & $9(81.8)$ \\
\hline & & & 14 & Adults & M & $4(28.6)$ & $10(71.4)$ \\
\hline & & & 14 & $(15-50)$ & $\mathrm{F}$ & $2(14.3)$ & $12(85.7)$ \\
\hline & & & 5 & Olds & $M$ & $2(40)$ & $3(60.0)$ \\
\hline & & & 5 & $(>50)$ & $F$ & $1(20)$ & $4(80.0)$ \\
\hline & Total & & 63 & & & $14(22.2)$ & 49 (77.8) \\
\hline Grand & & & 522 & & & $92(17.6)$ & 430 (82.4) \\
\hline
\end{tabular}

Table 6: Prevalence of IDDs in different altitudinal zones (by age and sex). Source: Sample survey, 2013.

From table 6, it is obvious that the soils are iodine deficient at all the elevation levels in the study area. The organic matter and $\mathrm{pH}$ influence the concentration of I in the soils. In soil type-61, iodine content first increases with altitude because of increase in $\mathrm{OM}$ in the soil and then slightly decreases with altitude due to increasing slope and coarser texture of soil. OM binds up iodine ions in the soil but the increasing slope and coarser texture cause iodine ions flow and translocate easily during rainfalls. In soil type-106, iodine content first decreases with 
Citation: Hajam RA, Rather GM, Kanth TA (2015) Etiological Study of Thyroid Disorders in the Foot Hill Settlements of Pir Panjal Range. J

Page 7 of 10

altitude because of increase in the acidity of the soil and then increases with altitude. The acidic $\mathrm{pH}$ in soil catalyzes the loss of iodine ions in soil through leaching.

Likewise, table 4 shows the concentration of iodine in drinking water sources in the area. Iodine content in drinking water sources first increases with altitude and then decreases. It shows affinity to the surrounding soils and their physico-chemical character.

\begin{tabular}{|c|c|c|c|c|c|c|}
\hline Macro Regions & Micro Regions & Sample Sites & Soil Type & $\begin{array}{l}\text { lodine Conc. (mg } \\
\text { kg-1) }\end{array}$ & $\mathrm{pH}$ & $\begin{array}{l}\text { Organic Matter (OM in } \\
\% \text { ) }\end{array}$ \\
\hline \multirow[t]{4}{*}{ LOWER FOOT HILLS } & \multirow{2}{*}{$\begin{array}{l}\text { LFHs-1 }(1,800-2,100 \\
\text { m AMSL) }\end{array}$} & SS1-ANG & 61 & 0.980 & 6.42 & 2.15 \\
\hline & & SS2-ANG & 106 & 1.000 & 6.51 & 3.76 \\
\hline & \multirow{2}{*}{$\begin{array}{l}\text { LFHs-2 }(2,100-2,400 \\
\text { m AMSL) }\end{array}$} & SS3-ANG & 61 & 1.230 & 6.28 & 3.76 \\
\hline & & SS4-ANG & 106 & 0.970 & 5.88 & 3.42 \\
\hline Mean & & & & 1.05 & 6.27 & 3.27 \\
\hline \multirow[t]{2}{*}{ UPPER FOOT HILLS } & \multirow{2}{*}{$\begin{array}{l}\text { UFHs }(2,400-3,000 \mathrm{~m} \\
\text { AMSL) }\end{array}$} & SS5-ANG & 61 & 1.050 & 6.42 & 4.90 \\
\hline & & SS6-ANG & 106 & 1.000 & 6.56 & 1.34 \\
\hline Mean & & & & 1.03 & 6.49 & 3.12 \\
\hline Mean & & & & 1.04 & 6.35 & 3.22 \\
\hline Standard Deviation & & & & $0.0893 \mathrm{mg} \mathrm{kg}-1$ & & \\
\hline Coefficient of SD & & & & 0.0859 & & \\
\hline Coefficient of Variation & & & & $8.6003 \%$ & & \\
\hline
\end{tabular}

Table 6: Iodine Content, pH and Organic Matter of Soil types. Source: Based on soil sample analysis done by the authors, 2013.

\section{Prevalence of iodine deficiency diseases}

The study revealed that about $17.6 \%$ people suffer from different IDDs in all the age-sex groups (Table 6). These people have greater $(66.89 \%)$ dependence on locally cultivated food items because of their disadvantaged economic condition. More than $62.4 \%$ households comprising low and medium income status households fall below poverty line as per international standards of income-based poverty lines (Rs. 2371.5 month $^{-1}$ person $^{-1}$ ). They also have inadequate income as per the local economic scenario is concerned. It is evident from the table 5 that in the sample village of UFH region, about $30.2 \%$ people suffer from IDDs as compared to $24.0 \%$ of LFH region. This variation can be attributed to the greater dependence of people on locally cultivated iodine deficit food items, and less use of iodized salt in UFHs than the people in LFHs (Table 7). In the sample village in UFHs, about $92.9 \%$ households fall in low and medium income groups (Table 8) which forces them to rely on whatever food items they cultivate locally. About $92.85 \%$ households have $>50 \%$ dependence on local iodine deficit foods and $42.8 \%$ people used iodized salt in UFHs as compared to the LFHs in which about $81.76 \%$ households in the sample villages have $>50 \%$ reliance on local foods and $75.4 \%$ people use iodized salt (Table 7).

\begin{tabular}{|c|c|c|c|c|c|c|c|c|c|c|}
\hline \multirow[t]{2}{*}{$\begin{array}{l}\text { Macro } \\
\text { Region }\end{array}$} & \multirow[t]{2}{*}{$\begin{array}{l}\text { Micro } \\
\text { Region }\end{array}$} & \multirow[t]{2}{*}{$\begin{array}{l}\text { Sample } \\
\text { Villages }\end{array}$} & \multirow[t]{2}{*}{$\begin{array}{l}\begin{array}{l}\text { Number of } \\
\text { Households } \\
\text { Surveyed }\end{array} \\
(100 \%)\end{array}$} & \multirow[t]{2}{*}{$\begin{array}{l}\text { Households } \\
\text { Drinking } \\
\text { Boiled Water } \\
(\%)\end{array}$} & \multirow[t]{2}{*}{$\begin{array}{l}\text { Households } \\
\text { Using lodized } \\
\text { Salt (\%) }\end{array}$} & \multicolumn{2}{|c|}{$\begin{array}{l}\text { Dependence on } \\
\text { Local food items } \\
(\%)\end{array}$} & \multirow{2}{*}{$\begin{array}{l}\text { Food } \\
\text { Purchased } \\
\text { from Market } \\
(\%)\end{array}$} & \multicolumn{2}{|c|}{$\begin{array}{l}\text { Methods of cooking } \\
\text { foods (\%) }\end{array}$} \\
\hline & & & & & & $<50 \%$ & $>50 \%$ & & Light2 & \\
\hline \multirow[t]{6}{*}{ LFHs } & \multirow[t]{2}{*}{ LFHs-1 } & SS1-ANG & 8 & $6(75)$ & $6(75.0)$ & 37.5 & 62.5 & 37.8 & $8(100)$ & $0(0)$ \\
\hline & & SS2-ANG & 52 & $35(67.3)$ & $40(76.9)$ & 00 & 100 & 23.85 & $50(96.2)$ & $2(3.8)$ \\
\hline & Total & & 60 & $41(68.3)$ & $46(76.7)$ & 18.75 & 81.25 & 30.83 & $58(96.7)$ & $2(3.3)$ \\
\hline & \multirow[t]{2}{*}{ LFHs-2 } & SS3-ANG & 29 & $14(48.3)$ & $19(65.5)$ & 3.45 & 96.55 & 30.17 & $25(86.2)$ & $4(13.8)$ \\
\hline & & SS4-ANG & 25 & $10(40)$ & $21(84.0)$ & 32 & 68 & 43.00 & $20(80.0)$ & $5(20.0)$ \\
\hline & Total & & 54 & $24(44.4)$ & $40(74.1)$ & 17.73 & 82.27 & 36.58 & $45(83.4)$ & $9(16.6)$ \\
\hline
\end{tabular}


Citation: Hajam RA, Rather GM, Kanth TA (2015) Etiological Study of Thyroid Disorders in the Foot Hill Settlements of Pir Panjal Range. J

Page 8 of 10

\begin{tabular}{|l|l|l|l|l|l|l|l|l|l|l|}
\hline \multicolumn{2}{|l|}{ Total } & & 114 & $65(57.02)$ & $86(75.4)$ & 18.24 & 81.76 & 33.71 & $103(90.4)$ & $11(9.6)$ \\
\hline UFHs & UFHs & SS5-ANG & 14 & $0(00)$ & $6(42.8)$ & 7.14 & 92.85 & 32.5 & $12(85.7)$ & $2(14.3)$ \\
\hline Grand Total & & 128 & $65(50.7)$ & $92(71.8)$ & 12.69 & 87.31 & 33.11 & $107(93.8)$ & $13(6.2)$ \\
\hline
\end{tabular}

Table 7: Showing Households Drinking Boiled Water, Households Using Iodized Salt, Dependence of People on Locally Cultivated Food Items and Methods of Cooking. Source: Sample Survey, 2013.Note: Deep1=Long period Boiling/Braising/Blanching/Frying, Light2=Short period Boiling/Braising/Blanching/Frying.

\begin{tabular}{|c|c|c|c|c|c|c|c|}
\hline \multirow{2}{*}{$\begin{array}{l}\text { Macro } \\
\text { Region }\end{array}$} & \multirow{2}{*}{$\begin{array}{l}\text { Micro } \\
\text { Region }\end{array}$} & \multirow{2}{*}{$\begin{array}{l}\text { Sample } \\
\text { Villages }\end{array}$} & \multirow{2}{*}{$\begin{array}{l}\text { Number } \\
\text { Households } \\
\text { Surveyed } \\
(100 \%)\end{array}$} & \multirow{2}{*}{$\begin{array}{l}\text { Average Family Size } \\
\text { (numbers) }\end{array}$} & \multicolumn{3}{|c|}{ Income Levels of Households Surveyed (Rs.\%) } \\
\hline & & & & & $\begin{array}{l}\text { Low } \\
(<5,000)\end{array}$ & $\begin{array}{l}\text { Medium } \\
(5,000-10,000)\end{array}$ & $\begin{array}{l}\text { High } \\
(>10,000)\end{array}$ \\
\hline \multirow[t]{6}{*}{ LFHs } & \multirow[t]{2}{*}{ LFHs-1 } & SS1-ANG & 8 & 6 & $2(25.0)$ & $2(25.0)$ & $4(50.0)$ \\
\hline & & SS2-ANG & 52 & 7 & $8(15.4)$ & $24(46.1)$ & $20(38.5)$ \\
\hline & & Total & 60 & 6.5 & $10(16.7)$ & $26(43.3)$ & $24(46.0)$ \\
\hline & \multirow[t]{2}{*}{ LFHs-2 } & SS3-ANG & 29 & 7 & $6(20.7)$ & $10(34.4)$ & $13(44.9)$ \\
\hline & & SS4-ANG & 25 & 6.5 & $5(20.0)$ & $10(40.0)$ & $10(40.0)$ \\
\hline & & Total & 54 & 6.75 & $11(20.4)$ & $20(37.0)$ & $23(42.6)$ \\
\hline \multicolumn{2}{|l|}{ Total } & & 114 & 6.63 & $21(18.4)$ & $46(40.4)$ & $47(41.2)$ \\
\hline UFHs & UFHs & SS5-ANG & 14 & 7.3 & $4(28.6)$ & $9(64.3)$ & $1(7.10)$ \\
\hline \multicolumn{3}{|c|}{ Grand Total } & 128 & 6.96 & $25(19.5)$ & $55(42.9)$ & $48(37.6)$ \\
\hline
\end{tabular}

Table 8: Income Levels of Households Surveyed (Rs.\%). Source: Sample Survey, 2013.

The prevalence of IDDs in LFHs shows a decline from LFHs-1 to LFHs-2. About $17.4 \%$ people suffer from IDDs in LFHs-1 as compared to $16.4 \%$ in LFHs-2 (Table 6). This variation seems to be outcome of the differential lifestyles especially the food cooking methods. In LFHs-1, about $96.7 \%$ households surveyed are accustomed to inappropriate cooking methods such as long period boiling, braising, blanching and frying as compared to LFHs- 2 in which the value is 83.4\% (Table 7).

The prevalence of IDDs in the sample villages in the sub-zones decreases with altitude with respect to changing iodine, $\mathrm{pH}$ and $\mathrm{OM}$ content in the respective soil types and socio-economic conditions with the exception of SS5-ANG. In the LFHs-1, SS1-ANG (soil type-61) records $21.4 \%$ and SS2-ANG (soil type-106) records $16.9 \%$ of patients and in LFHs-2, SS3-ANG (soil type-61) records $16.4 \%$ and SS4-ANG (soil type-106) records $16.5 \%$ of patients and in UFH subzone, SS5-ANG (soil type-61) experiences $22.2 \%$ of patients to its total surveyed population. The increase in the percentage of patients suffering from IDDs in SS5-ANG is due to high (4.90\%) OM in soil (Table 4). Though the concentration of iodine at SS5-ANG is relatively greater than some of the other sites, it has the disadvantage of having high OM. The OM decreases the bioavailability of iodine for the plants/crops resulting in iodine deficient foods. It may also be attributed to the greater dependence of the people on local foods (Table 7). Difference in the percentage prevalence of IDDs with respect to age and sex groups can be attributed to the relative differences in the life styles.

A diagrammatic model (Figure 6) has been developed related to the present study that shows cyclic movement of the iodine in the different phases of environment, the pathways how iodine reaches to the human body, its losses at different stages of movement at the dual hands of nature and humankind and the consequent results i.e., IDDs. The diagram also highlights the role of natural pools of iodine transfer and the life style of the people of the area under study in contributing the causation of the different IDDs. The lithospheric and atmospheric pools of iodine cycle are iodine deficient while as the hydrospheric pool is efficient in iodine content but not sufficient to save human beings from IDDs. So, the food derived from the soil is deficient in iodine. An individual human being derives only about $0.5 \mu \mathrm{g} \mathrm{d}^{-1}$ of iodine from inhalation [18]. The marine food is rich in iodine but unfortunately people make less use of marine foods perhaps because of their low income status and high price of the food. The problem of iodine deficiency and loss from the whatsoever food and water is used is further coupled by the unsuitable and unhealthy cooking methods and other lifestyles. 
Citation: Hajam RA, Rather GM, Kanth TA (2015) Etiological Study of Thyroid Disorders in the Foot Hill Settlements of Pir Panjal Range. J

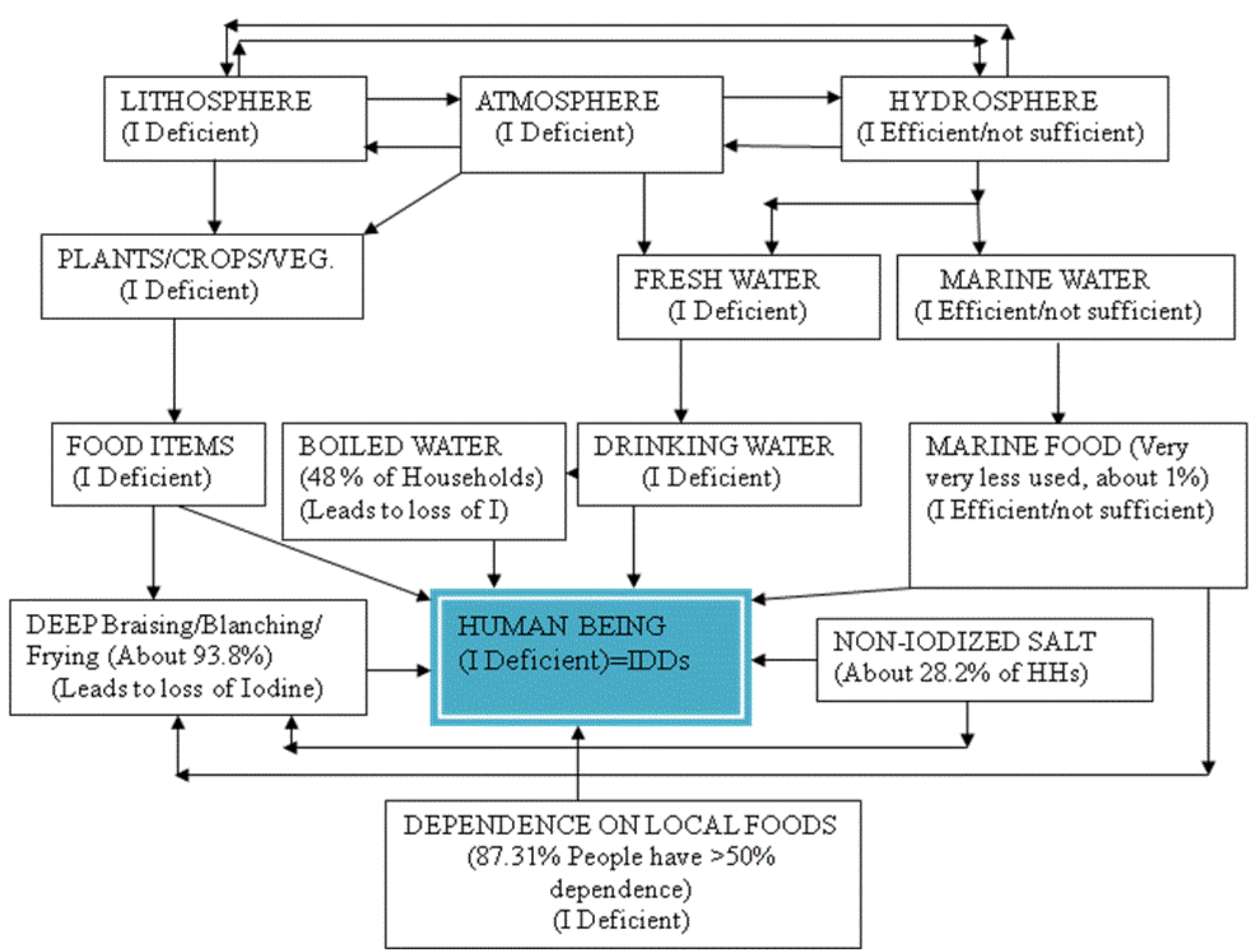

Figure 6: Schematic diagram showing transfer and loss of iodine at different stages of iodine transfer and the consequent results in human beings (Developed by the Authors).

\section{Conclusions}

In all the altitudinal zones, the iodine content in the soil (0.970-1.230 $\left.\mathrm{mg} \mathrm{kg}^{-1}\right)$ and fresh (drinking) water (1.6-4.2 $\left.\mu \mathrm{g} \mathrm{L}^{-1}\right)$ sample sites is less than the world level averages in soils $\left(2.8 \mathrm{mg} \mathrm{kg}^{-1}\right)$ and drinking water $\left(8.7 \mu \mathrm{g} \mathrm{L}^{-1}\right)$ sources. The iodine content in soils showed a close association with $\mathrm{OM}$ and $\mathrm{pH}$. Iodine in soils has direct relationship with $\mathrm{OM}$ and inverse relationship with $\mathrm{pH}$. Iodine content in water samples showed a relationship with iodine content in surrounding soils. Leaching and run-off play an important role in the transfer of iodine from surroundings soils to water bodies. About $17.6 \%$ people surveyed suffer from thyroid disorders. There is decrease in the prevalence of IDDs from LFHs to UFHs and from LFHs-1 to UFHs-2 because of the lifestyle of people. At sample village level, there is also a decrease in the percentage prevalence of IDDs with altitude in respective soil types except SS5-ANG of UFH region. This is due to high (4.90\%) OM in soil at SS5-ANG and dependence on vegetarian food.

\section{Suggestions}

Certain simple and low cost suggestions to minimize the magnitude of IDD sufferers in the area under study are needed for the area is rural in character. The people of the area should make $100 \%$ use of iodized salt by the whole population. Special care should be taken of pregnant and nursing mothers after consulting a registered medical practitioner. They should avoid long period boiling, braising, blanching and frying of foods to avoid the loss of nutrients especially iodine. Iodine should be added to drinking water and the irrigational water through fertigation to increase the content of iodine in the natural systems of soil and water. More and more sea foods, eggs, dairy products, watercresses, iodized salt, grains, and fruits should be used. The people should also avoid drinking of boiled water in coliform risk free areas.

\section{Acknowledgment}

The authors are highly thankful and indebted to University Grants Commission for providing financial assistance in terms of Junior Research Fellowship to Mr. Rafiq Ahmad Hajam, Ph.D research scholar, department of Geography and Regional Development, University of Kashmir.

\section{References}

1. Adriano DC (2001) Trace Elements in Terrestrial Environments: Biogeochemistry, Bioavailability and Risks of Metals. Springer-Verlaug, Inc, 175 Fifth Avenue, , New York, USA 225:1-24. 
Citation: Hajam RA, Rather GM, Kanth TA (2015) Etiological Study of Thyroid Disorders in the Foot Hill Settlements of Pir Panjal Range. J Health Edu Res Dev 3: 138. doi:10.4172/2380-5439.1000138

Page 10 of 10

2. Warren H (1991) Geology and Health. In: Akhtar R (Ed) Environment and Health: Themes in Medical Geography. APH New Delhi pp: 297-313.

3. World Health Organization (1996) Trace Elements in Human Nutrition and Health. WHO, Geneva pp. 62-138.

4. Hunter J, Akhtar R (1991) The Challenge of Medical Geography. In: Akhtar R (Eds.) Environment and Health, Themes in Medical Geography. Ashish Publishing House, New Delhi pp: 1-37.

5. Keller E (1999) Environmental Geology. Merrill Prentice Hall Upper Saddle River, New Jersey pp: 314-316.

6. Pyle GF (1979) Applied Medical Geography. VH Winston and sons (Eds) Washington, DC p: 88.

7. Masoodi S (2012) Goitre or Iodine Deficiency Disorder - There is More Than Meets the Eye. J Medical Sciences 15:1.

8. Fuge R (2005) Soils and Iodine Deficiency. In: Selinus O et al. (Eds.) Essentials of Medical Geology, Impacts of the Natural Environment on Public Health. Elsevier Academic Press p: 426.

9. Jamescon JL, Weetman AP (2005) Disorders of the thyroid gland. In: Kasper DL, Braunwald E, Fauci AS (Eds.) Harrison's Principles of Internal Medicine. New York, McGraw Hill pp: 2104-2127.

10. United Nations Children's Fund (2002) Iodine Deficiency Disorders and Universal Salt Iodization: South Asia Priorities. UNICEF Regional Office for South Asia, Kathmandu-5815, Nepal pp: 4-5.
11. Zimmermann MB (2009) Iodine deficiency. Endocr Rev 30: 376-408.

12. Mayer IA (2004) Geographical Distribution of Goiter in Kashmir Valley. In: Izhar N (Edn) Geography and Health-A Study in Medical Geography, APH, New Delhi pp: 89-101.

13. Khan MS, Mahjabeen R, Masoodi MA, Kauser J, Shahnaz N (2014)Prevalence of goiter among primary school children of Kulgam district, Jammu and Kashmir, India. Academic Medical Journal of India 3:18-21.

14. Census of India (2011) District Census Handbook, Anantnag.

15. Raza M, Ahmad A, Mohammad A (1978) The Valley of Kashmir: A Geographical Interpretation-The Land. Vikas Publication House, New Delhi pp: 1-117.

16. Brady NC (1991) Nature and Properties of Soils. Macmillan Publishing Company, New York p: 247.

17. Pennock D, Yates T, Braidek J (2008) Soil Sampling Designs. In: Carter MR, and Gregorich EG (Eds) Soil Sampling and Methods of Analysis. Canadian Society of Soil Science pp: 3-14.

18. Nordic Project Group (1995) Risk Evaluation of Essential Trace Elements-Essential versus Toxic Levels of Intake. Nordic Council of Ministers, Nord p: 18. 